\title{
E-PELAYANAN KONSULTASI KESEHATAN PEDULI REMAJA PADA PUSKESMAS BEKASI
}

\author{
Heru Purwanto \\ Program Studi Manajemen Informatika \\ AMIK BSI Bekasi \\ Email: heru.hrp@bsi.ac.id \\ Sopiyan Dalis \\ Program Studi Manajemen Informatika \\ AMIK BSI Bekasi \\ Email: Sopiyan.spd@bsi.ac.id
}

\begin{abstract}
ABSTRAK
Aktivitas dengan intesitas yang tinggi memberikan keterbatasan dalam membagi waktu dan kesempatan untuk berkumpul dan bercerita bersama keluarga. Pemanfaatan internet memberikan kesempatan untuk mendapatkan informasi yang terkini dimanapun dan kapanpun, salah satunya ialah kegiatan konsultasi kesehatan khususnya bagi remaja. Ini merupakan peluang sebagai kesempatan untuk menjembatani adanya komunikasi yang dapat dilakukan secara online. Dengan mensinergikan Program Pelayanan Kesehatan Peduli Remaja (PKPR) melalui sistem informasi konsultasi berbasis web secara online menjadi wadah informasi bagi remaja dalam pelayanan seputar konseling kesehatan dan pendidikan ketrampilan hidup sehat yang disampaikan dengan cara menyenangkan serta tetap menghargai dan menjaga kerahasian user.Metode Waterfall digunakan untuk perancangan sistem aplikasi online. Teknis perancangan sistem dengan menggunakan UseCase Diagram dan Activity Diagram serta Entity Relationship Diagram (ERD).Aplikasi MySql Server, Webserver digunakan untuk mendukung pembuatan Basis Data. Potensi pengembangan penyuluhan dan konsultasi menjadi acuan untuk analisis berikutnya dengan menggunakan metode Critical Succes Factor (CSF) dalam mendukung pemetaan strategi yang lebih efektif dan efisien. Metode pendekatan Customer Relationship Management (CRM) melalui operasional, analitik dan collaborative menjadi tolak ukur dalam pembuatan situs E-Pelayanan agar sesuai dengan kebutuhan dalam mendapatkan hubungan yang baik dengan Anggota. Hasil dari penelitian ini, dapat memberikan masukan dan manfaat, khususnya pada kegiatan pelayanan kesehatan dan penyuluhan remaja (PKPR) di puskesmas wilayah Bekasi dan sekitarnya. Pengujian T test dengan Uji statistik $\mathrm{t}_{\text {hit }}(\mathrm{n}<30), \alpha=0.05$ dilakukan Untuk mengukur efektivitas pengaruh aplikasi sistem konsultasi kesehatan berbasis web, dimana hasilnya adalah $\mathrm{t}_{\text {hit }}=3.08>\mathrm{t}$ 0,05;25 $=2,060$ menunjukan ada pengaruh anggota untuk dapat meningkatkan cara hidup sehat melalui informasi konsultasi kesehatan berbasis web.
\end{abstract}

Kata kunci: konsultasi, e-pelayanan, CRM, ERD, waterfall, CSF.

\begin{abstract}
Activities with high intensity give limitations in sharing time and opportunities to gather and tell stories with family. Utilization of the internet provides an opportunity to obtain the latest information wherever and whenever, one of which is a health consultation activities, especially for teenagers. This is an opportunity as an opportunity to bridge the communication that can be done online. By synergizing the Program Pelayanan Kesehatan Peduli Remaja (PKPR) with an online web-based consultation information system to be an information container for teenagers in health care counseling and life skills education services delivered in a fun way and still respect and keep the user confidential. Waterfall method is used for the design of online application system. Technical design of the system using the Use Case Diagram and Activity Diagram and Entity Relationship Diagram (ERD). MySql Server application, Webserver are used to support the making of Database. the potential for extension and consultation development becomes the reference for subsequent analysis using the Critical Success Factor (CSF) method to support the mapping of more effective and efficient strategies.Customer Relationship Management (CRM) method through operational, analytic, campaign and collaborative management becomes benchmark in making E-Pelayanan website to fit the needs of getting a good relationship with Members. The results of this study, can provide input and benefits, especially on Program health care for youth $(P K P R)$ in puskesmas Bekasi and surrounding areas. T test with statistical test $t$ hit $(n<30), \alpha=$
\end{abstract}


0.05 To measure the effectiveness of application effect of web-based health consultation system, where the result is $t$ hit $=3.08>t 0.05 ; 25=2.060$ indicates there is influence member to improve healthy ways of living through web-based health consultation information.

Keywords: consultation, e-pelayanan, CRM, ERD, waterfall, CSF.

\section{PENDAHULUAN}

Kemajuan teknologi berkembang sangat cepat sehingga membawa dampak pada perubahan lingkungan dan informasi melalui berbagai media. Informasi yang beragam terlepas dari sifatnya yang dapat bernilai positif atau negatif akan mempengaruhi timbulnya suatu masalah, khususnya masalah pada remaja. Masalah-masalah yang sering dihadapi oleh remaja seperti masalah reproduksi dan penyakit, pergaulan yang kurang baik dan psikososial.

Puskesmas memiliki peran penting dalam kegiatan pelayanan kesehatan dimasyarakat. Berlokasi di Jl. Karang Satria Raya No.218, Karangsatria, Tambun Utara. Saat ini penyampaian informasi pada puskesmas karang Satria dilakukan secara manual seperti menempel poster-poster atau pengumuman pada tembok dan melalui xbanner. Selanjutnya kendala waktu yang diperlukan pada saat konsultasi dengan dokter sangat terbatas mengingat banyaknya antrian dari pasien yang berkunjung.

Tuntunan kebutuhan akan informasi dan penggunaan komputer yang semakin banyak mendorong terbentuknya sebuah jaringan komputer yang mampu melayani berbagai kebutuhan tertentu. Dengan adanya jaringan komputer, pengelolaan informasi dapat berlangsung lebih baik lagi. Berkembangnya teknologi dan kebutuhan akan informasi menyebabkan bertambah kompleksnya informasi yang harus dan yang bias diolah, sehingga kebutuhan penggunaan jaringan komputer semakin diperlukan. Penggunaan jaringan secara bersama sama ini tumbuh membentuk jaringan komputer yang amat besar yang tersebar diseluruh bagian di muka bumi ini [1].

Perancangan sistem Informasi diawali kegiatan analisa data dan informasi dengan menggunakan Critical Success Factor (CSF) sebagai dasar pemetaan strategi pelayanan dan operasional [2].Pembangunan dan pembuatan program mengacu pada tahapan-tahapan pada metode Waterfall [3].

Penerapan konsep Manajemen Hubungan Pelanggan (CRM) dapat diterapkan untuk memberikan peningkatan pelayanan bagi pasien atau Anggota. Kerangka komponen diklasifikasikan dalam operasional, analitikal dan collaborative [4].

\section{METODOLOGI PENELITIAN}

Kerangka komponen CRM diklasifikasikan menjadi tiga yaitu [5]:

a. Operasional CRM: Operasional CRM dikenal sebagai front office perusahaan.Komponen CRM ini berperan dalam interaksi dengan pelanggan. Operasional CRMmencakup proses otomatisasi yang terintegrasi dari keseluruhan proses bisnis, seperti otomatisasi pemasaran, dan pelayanan. Salah satu penerapan CRM yang termasuk dalam kategori operasional CRM adalah dalam bentuk aplikasi web. Melalui web, suatu perusahaan dapat memberikan pelayanan kepada pelanggan.

b. Analitikal CRM: Analitikal CRM dikenal sebagai back office perusahaan. Komponen CRM ini berperan dalam memahami kebutuhan pelanggan. Analitikal CRM berperan dalam melaksanakan analisis pelanggan dan pasar, seperti analisis trend pasar dan analisis kebutuhan dan perilaku pelanggan. Data yang digunakan pada CRM analitik adalah data yang berasal dari CRM operasional.

c. Collaborative CRM: Komponen kolaborasi CRM meliputi e-mail, personalized publishing, ecommunities, dan sejenisnya yang dirancang untuk interaksi antara pelanggan dengan perusahaan. Tujuan utamanya adalah memberikan nilai tambah dan memperluas loyalitas pelanggan ke pelanggan lain yang masih belum berada di level kesetiaan pelanggan. Collaborative CRM juga mencakup pemahaman atau kesadaran bahwa pelanggan yang setia dapat menjadi magnet bagi pelanggan lain

Menurut [6], CRM terdiri dari fase-fase sebagai berikut:

a. Mendapatkan pelanggan baru (Aquire): Pelanggan baru didapatkan dengan memberikan kemudahan pengaksesan informasi, inovasi baru, dan pelayanan yang menarik.

b. Meningkatkan nilai pelanggan (Enhance): Perusahaan berusaha menjalin hubungan dengan pelanggan melalui pemberian pelayanan yang baik terhadap pelanggannya (customer service).

c. Mempertahankan pelanggan yang telah ada (Retain): Mempertahankan pelanggan yang memberi keuntungan, dengan menawarkan apa yang dibutuhkan oleh pelanggan spesifik bukan yang dibutuhkan oleh pelanggan pasar, karena nilai produk atau jasa bagi pelanggan adalah nilai 
proaktif yang paling sesuai dengan kebutuhannya. Fokus perusahaan saat ini adalah bagaimana mempertahankan pelanggan yang sudah ada pasti memberikan keuntungan bagi perusahaan daripada bagaimana mendapatkan pelanggan baru yang belum tentu menguntungkan.

Menurut [7], manfaat Customer Relationship Management adalah:

a. Mendorong loyalitas pelanggan: Aplikasi CRM memungkinkan perusahaan untuk memanfaatkan informasi dari semua titik kontak dengan pelanggan, baik melalui web,call center, atau melalui staf pelayanan di lapangan. Dengan adanya konsistensi dan kemudahan dalam mengakses dan menerima informasi, maka bagian pelayanan akan dapat memberikan layanan yang lebih baik lagi kepada pelanggan dengan memanfaatkan berbagai informasi penting mengenai pelanggan tersebut.

b. Mengurangi biaya: Dengan penerapan CRM, memungkinkan pelayanan terhadap pelanggan memiliki skema informasi yang spesifik dan terfokus, serta dengan menargetkan pelayanan pada pelanggan yang tepat pada saat yang tepat. Dengan demikian, biaya yang dikeluarkan akan menjadi tergunakan secara maksimal dan tidak terbuang percuma yang berujung pada pengurangan biaya.

c. Meningkatkan efisiensi operasional: Kemudahan proses penjualan dan layanan akan dapat mengurangi resiko turunnya kualitas pelayanan dan mengurangi beban cash flow.

Perancangan sistem ini menggunakan Metode waterfall. Metode waterfall (air terjun) Menurut [8]"metode SDLC air terjun (waterfall) sering juga disebut model sekuensial linear (sequential linear) menyediakan pendekatan alur hidup perangkat lunak secara sekuensial atau terurut dimulai dari analisa, desain, pengkodean, pengujian, dan tahap pendukung (support)

\section{The classic waterfall development model}

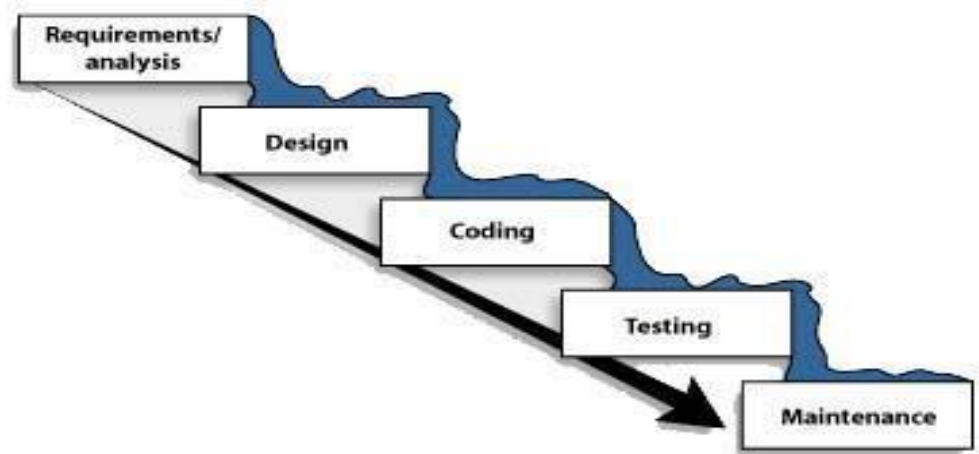

Gambar 1. Metode Waterfall [9].

Tahapan pengembangan sistem menggunakan model air terjun (waterfall) ini terbagi menjadi beberapa proses, yaitu [8]:

a. Analisa kebutuhan

Pemetaan strategi operasional dilakukan dengan menggunakan Critical Success Factor (CSF).

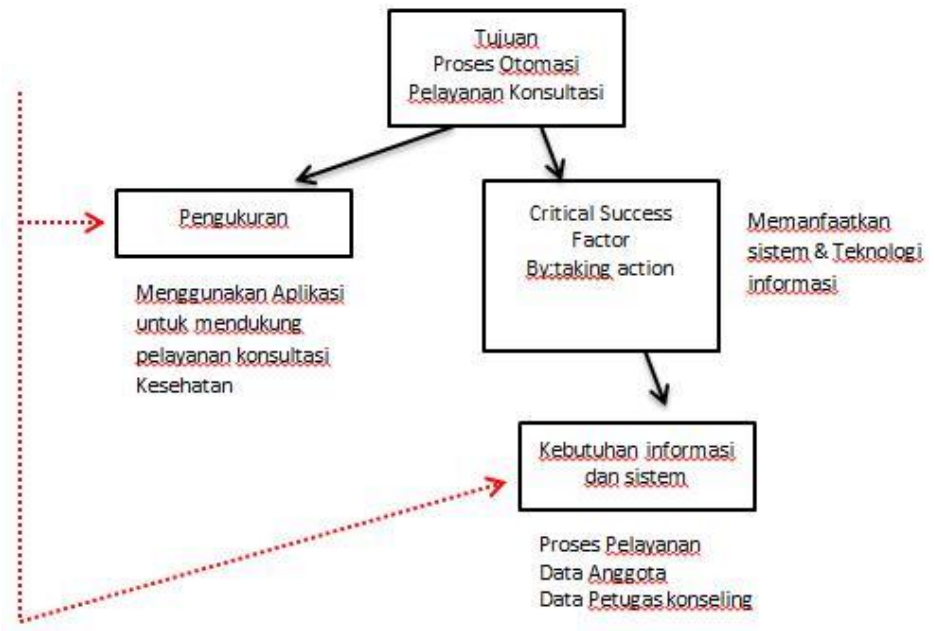

Gambar2. Prespektif Proses Otomasi Pelayanan Konsultasi 
Dari sisi sistem yang dibutuhkan adalah database karena semua aplikasi web yang akan dibuat semua terhubung ke database dan akan melakukan tiga tahap yaitu input proses dan output. Sedangkan dari sisi pengguna yang dibutuhkan adalah berapa banyak yang dapat mengakses web tersebut seperti user, member dan admin.

b. Perancangan Sistem dan Perangkat Lunak Dalam perancangan aplikasi web ini penulis menggunakan Teknis perancangan sistem dengan menggunakan UseCase Diagram dan Activity Diagram, ERD dan Spesifikasi file agar sistem yang dibuat tersusun dengan baik. Untuk perangkat lunak yang digunakan adalah XAMPP, MySQL, dan Adobe Dreamweaver CS.6.

c. Pengujian Unit dan Implementasi. Pengujian unit menggunakan BlackBox Testing untuk meminimalisir kesalahan yang akan terjadi pada saat aplikasi dijalankan Implementasinya adalah pembuatan web.

\section{HASIL DAN PEMBAHASAN}

\subsection{Konsep E Pelayanan pada Aplikasi}

a. Kebutuhan Pengguna

Dari sisi pengguna yang dibutuhkan adalah berapa banyak yang dapat mengakses web tersebut seperti pengunjung, anggota dan admin. Untuk pengguna hak aksesnya dapat melihat informasi pelayanan kesehatan, artikel kesehatan, dan registrasi sebagai Anggota. Untuk Anggota hak aksesnya dapat melakukan konseling, berbagi pengalaman dan melihat respon konseling.Untuk admin dapat melihat dan menjawab data konseling, data Anggota, dan melihat laporan.

b. Kebutuhan Sistem

Dari sisi sistem yang dibutuhkan adalah database karena semua aplikasi web yang akan dibuat semua terhubung ke database dan akan melakukan tiga tahap yaitu input, proses dan output sedangkan form yang dibutuhkan adalah form pendaftaran data Anggota, form Login Anggota, form data Konseling, form data Berbagi Pengalaman, form login Admin, form Jawab Konseling dan data laporan.

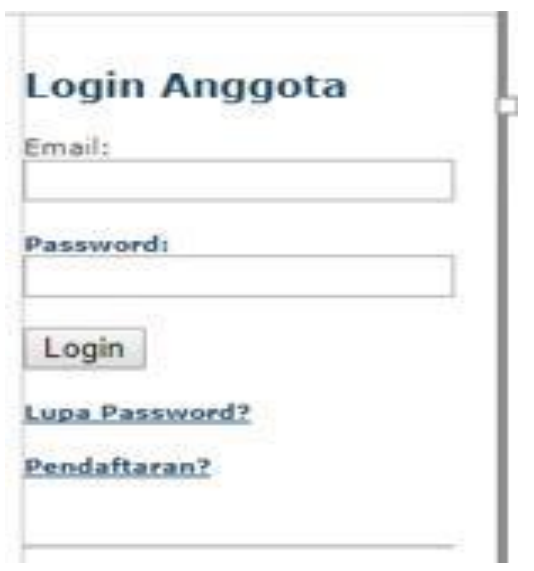

Gambar 3. Rancangan Antar Muka Login Anggota

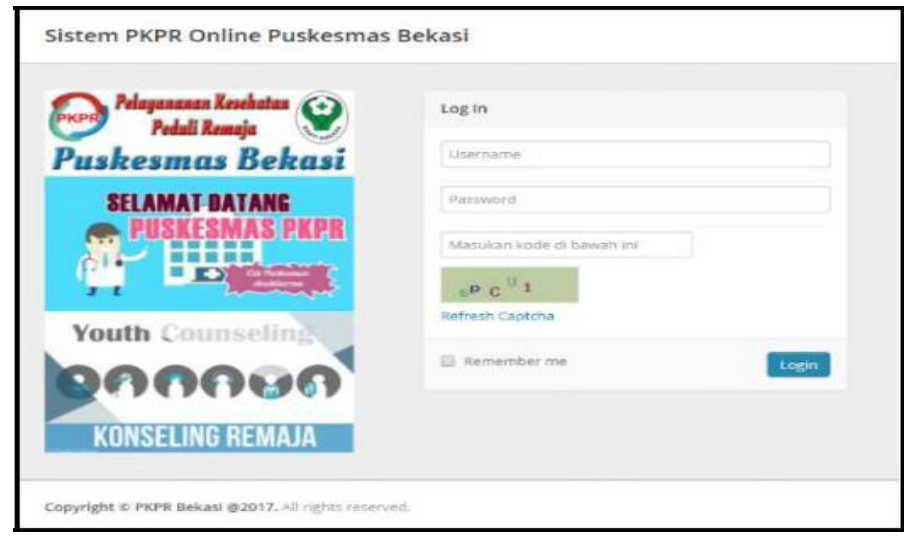

Gambar 4. Rancangan Antar Muka Login Admin 


\subsection{Aplikasi E-Pelayanan Yang Dirancang Untuk Memenuhi Tahap Crm}

\subsubsection{Tahap Acquire}

Pendaftaran Anggota (Daftar Member) dirancang untuk memberikan kesempatan kepada pengunjung untuk bergabung menjadi anggota. Setelah berhasil menjadi anggota maka dapat memanfaatkan feature konsultasi dan berbagi pengalaman. Gambar 5 dan 6 adalah salah satu dari tahap acquire .

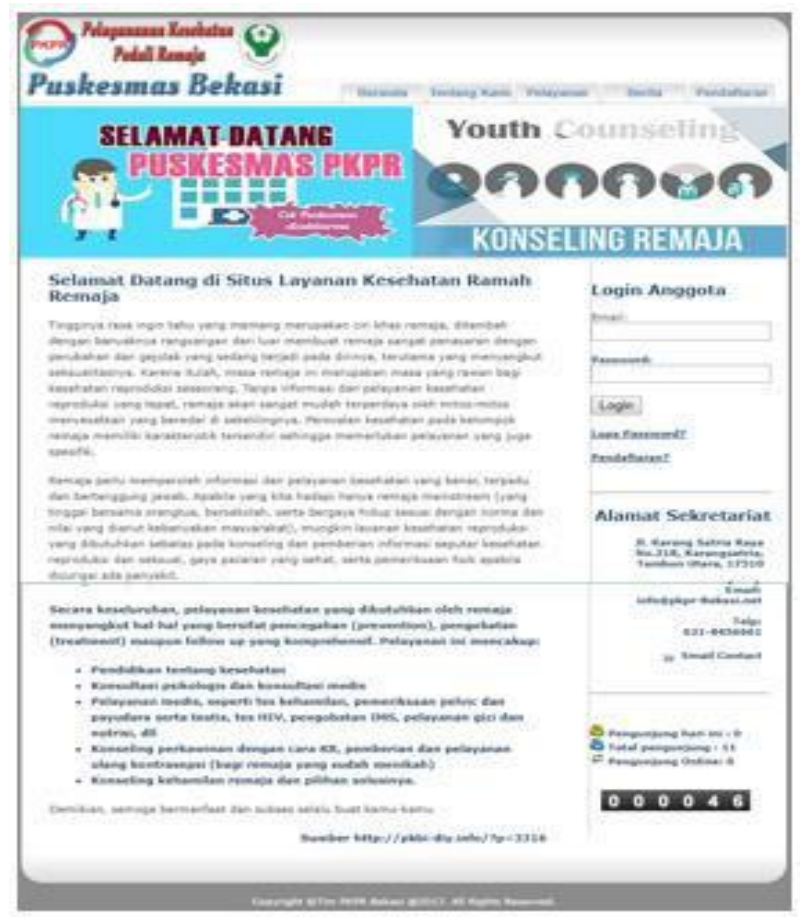

Gambar 5. Halaman Beranda Utama

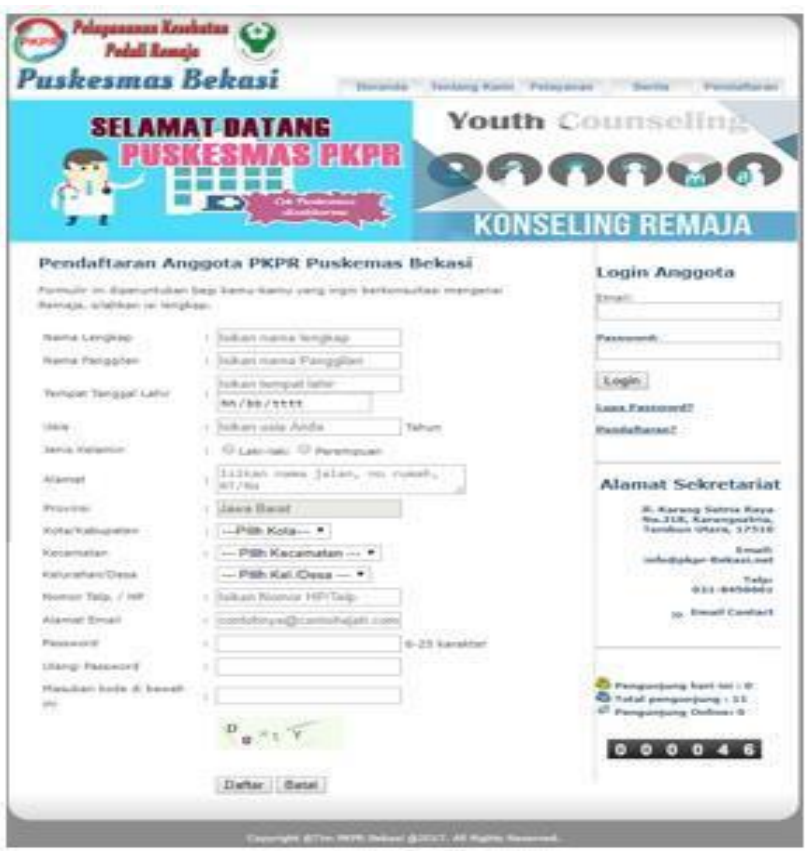

Gambar 6. Pendaftaran Anggota 


\subsubsection{Tahap Enhance}

Pemberian pelayanan yang baik kepada Anggota melalui kemudahan dalam berkonsultasi dan berbagi pengalaman seperti menyediakan halaman konsultasi dan berbagi pengalaman dengan tetap menjaga privasi dan kerahasian anggota.

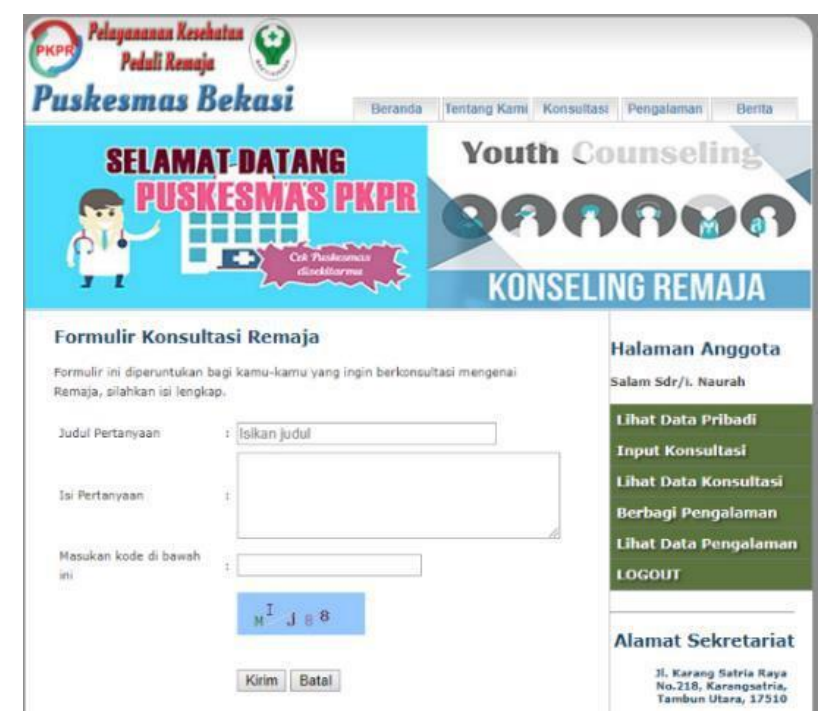

Gambar 7. Rancangan Form Input Konseling

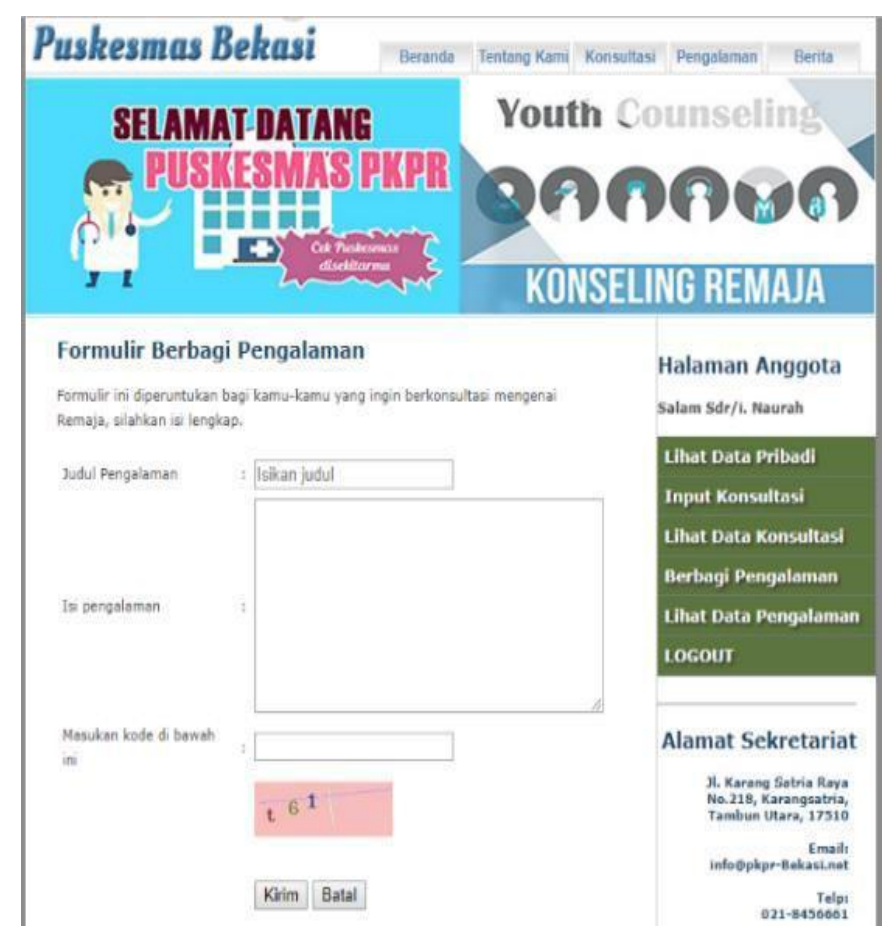

Gambar 8. Rancangan Form Input Berbagi Pengalaman

\subsubsection{Tahap Retain}

Respon yang cepat dan update data serta informasi terbaru merupakan bentuk pelayanan agar anggota dapat dengan setia selalu berkunjung untuk mendapatkan informasi dan berkonsultasi. 


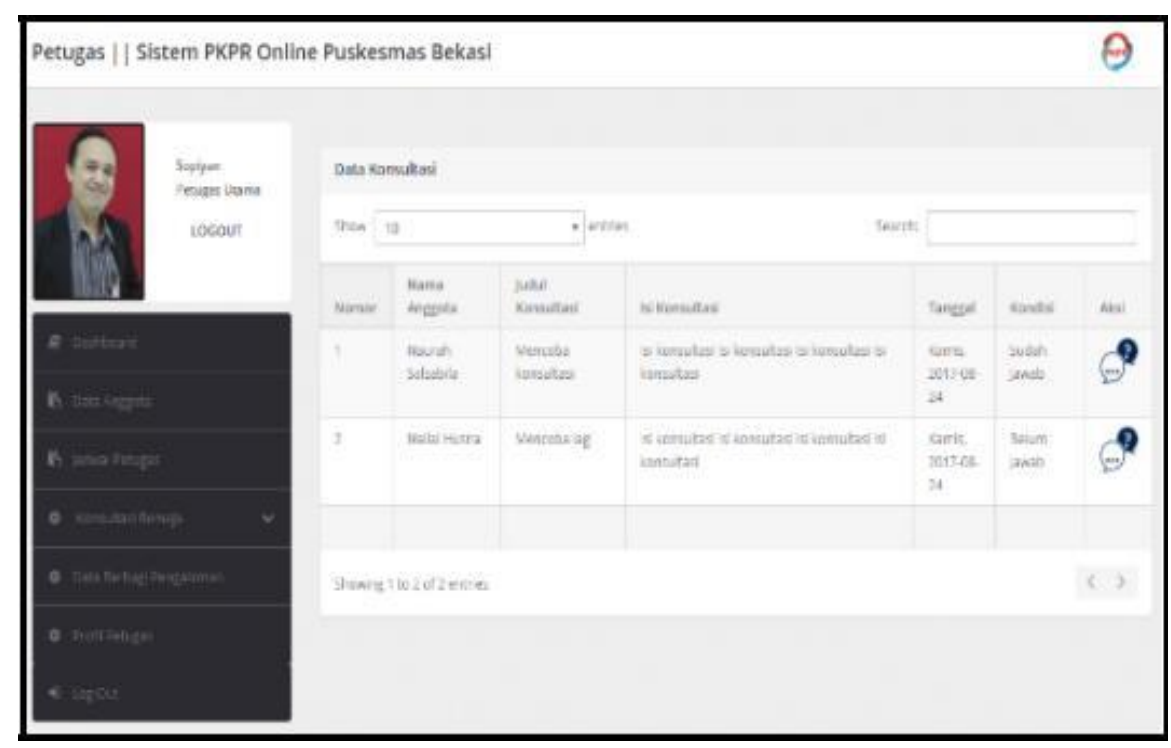

Gambar 9. Antar Muka Kegiatan Konsultasi

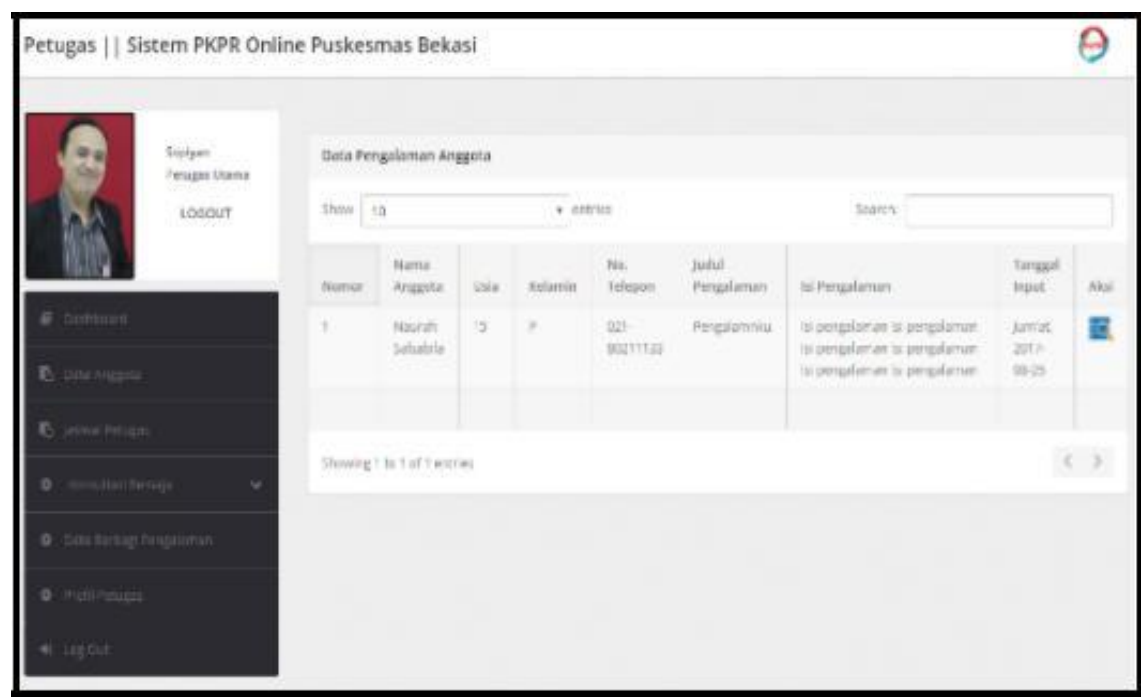

Gambar 10. Antar Muka Berbagi Informasi Dan Pengalaman

\subsubsection{Rancangan Use Case Diagram}

Rancangan use case konsultasi online memberikan gambaran konteks tentang proses kegiatan anggota setelah berhasil login. Anggota dapat melakukan kegiatan konsultasi atau berbagi dengan mengisi form yang disediakan Admin atau petugas admin akan mengecekdan form pertanyaan setelah itu pertanyaan menganalisa pertanyaan yang disampaikan kemudian memberikan saran atau altenarif solusi. Dalam waktu periodik tertentu admin akan membuat laporan kegiatan konsultasi. Laporan ini dapat dijadikan sebagai history file Anggota. 


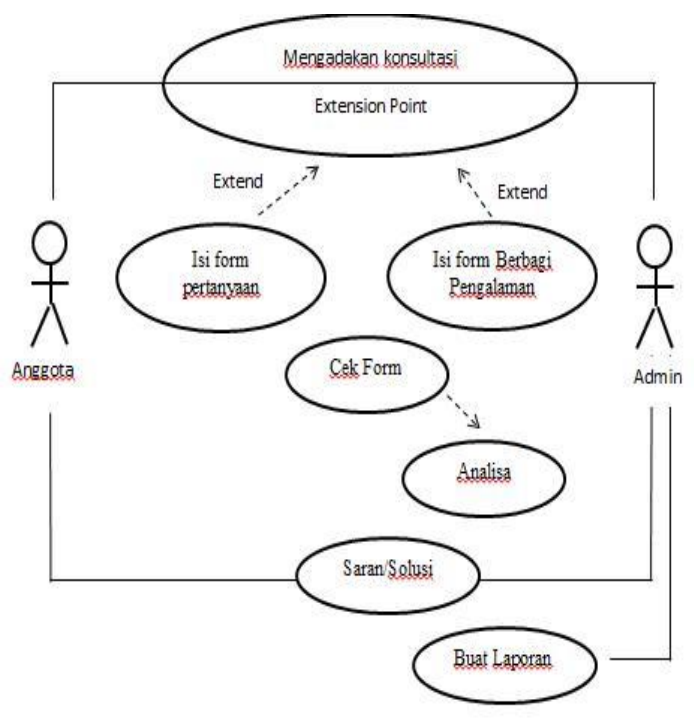

Gambar 11. Usecase Sistem Konsultasi Online

\subsubsection{Rancangan Activity Diagram Konsultasi Anggota}

Pada alur konsultasi online, anggota harus terlebih dahulu melakukan Pendaftaran bila berhasil data akan tersimpan dan anggota bisa melakukan langsung melakukan konsultasi online. Petugas akan menerima data konsultasi dan melakukan diagnosa, setelah itu petugas akan memberikan solusi secara komputerisasi. Sebelum selesai petugas akan melakukan pengkinian data terbaru untuk disimpan pada data History anggota.

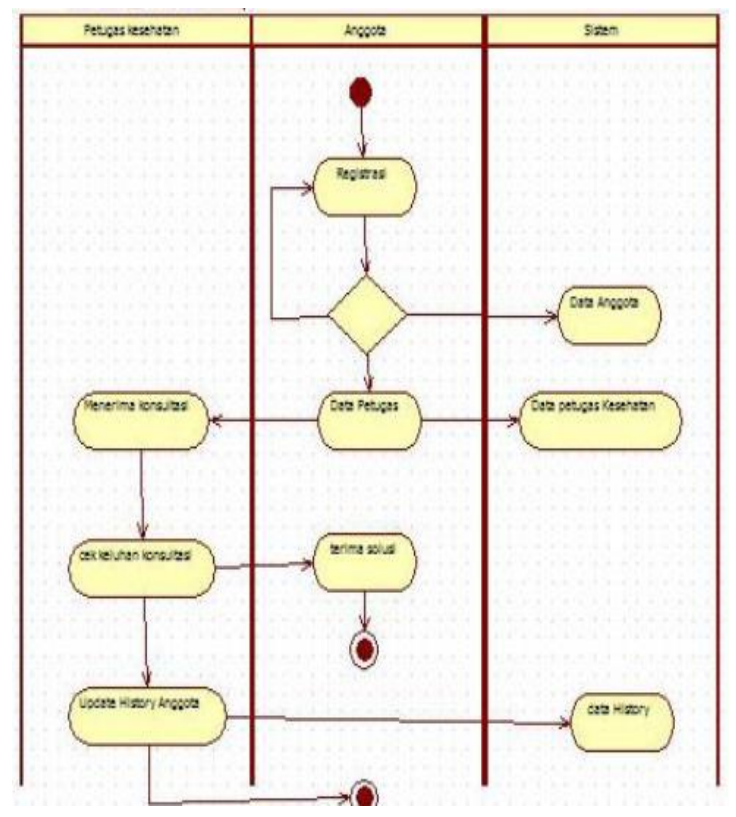

Gambar 12. Desain Activity Diagram Konsultasi Online

\subsubsection{Rancangan Entity Relationship Diagram (ERD)}

Menurut [10], ERD (Entity Relationship Diagram) adalah "sebuah diagram yang menggambarkan hubungan/relasi antar entitas (Entity), dan setiap entity terdiri atas satu atau lebih atribut yang mempresentasikan seluruh kondisi (fakta) dari dunia nyata yang kita tinjau. Dengan ERD kita berusaha untuk mentransformasikan keadaan dari dunia nyata kedalam bentuk basis data”. Derajat keterhubungan diperlukan untuk memberikan tingkat hubungan antar entity. 


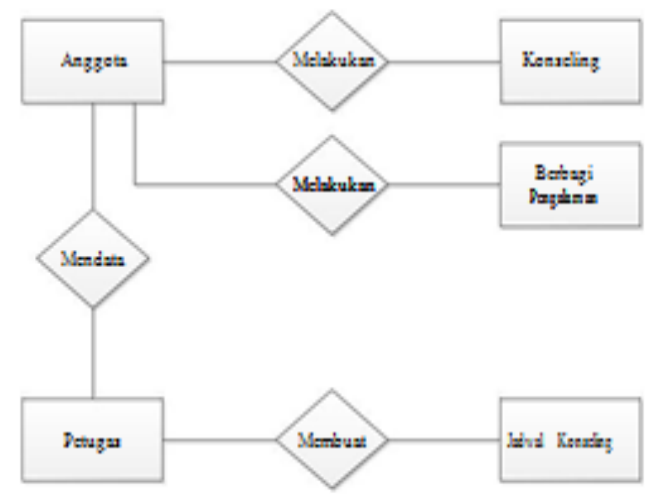

Gambar 13. Perancangan ERD Konsultasi Berbasis Web

\subsubsection{Black Box Testing}

Pengujian sistem yang dibuat dengan menggunakan black box testing untuk pengujian proses input dan output. Pengujian ini bertujuan untuk menunjukkan fungsi perangkat lunak tentang cara teknis pengoperasian sistem. Lebih spesifik, metode ini bertujuan untuk mencari kesalahan pada:
a. Fungsi yang salah/hilang
b. Kesalahan pada interface
c. Kesalahan pada struktur data/akses database
d. Kesalahan performa
e. Kesalahan instalasi dan tujuan akhir

Salah satu bentuk uji coba black box adalah testing validasi. Uji coba ini dinyatakan berhasil jika fungsi- fungsi yang ada pada perangkat lunak sesuai dengan apa yang diharapkan pemakai

a. Pengujian form login admin

Tabel 1. Hasil pengujian black box testing login admin

\begin{tabular}{|c|c|c|c|c|c|}
\hline No. & $\begin{array}{c}\text { Skenario } \\
\text { Pengujian }\end{array}$ & Test Case & $\begin{array}{c}\text { Hasil yang } \\
\text { Diharapkan }\end{array}$ & $\begin{array}{c}\text { Hasil } \\
\text { Pengujian }\end{array}$ & Kesimpulan \\
\hline 1 & $\begin{array}{l}\text { Username dan } \\
\text { Password tidak } \\
\text { diisi kemudian } \\
\text { klik tombol } \\
\text { Login }\end{array}$ & $\begin{array}{l}\text { Username: } \\
\text { (kosong) } \\
\text { Password: } \\
\text { (kosong) }\end{array}$ & $\begin{array}{l}\text { Sistem akan } \\
\text { menolak dan } \\
\text { menampilkan pesan } \\
\text { "Harap isi username } \\
\text { dan password" }\end{array}$ & $\begin{array}{l}\text { Sesuai } \\
\text { harapan }\end{array}$ & sukses \\
\hline 2 & $\begin{array}{l}\text { Mengetikkan } \\
\text { Username, dan } \\
\text { password tidak } \\
\text { diisi atau } \\
\text { kosong } \\
\text { kemudian klik } \\
\text { tombol Login }\end{array}$ & $\begin{array}{l}\text { Username: } \\
\text { admin } \\
\text { Password: } \\
\text { (kosong) }\end{array}$ & $\begin{array}{l}\text { Sistem akan } \\
\text { menolak dan } \\
\text { menampilkan pesan } \\
\text { "Password belum } \\
\text { diisi"" }\end{array}$ & $\begin{array}{l}\text { Sesuai } \\
\text { harapan }\end{array}$ & sukses \\
\hline 3 & $\begin{array}{l}\text { Mengetikkan } \\
\text { Password, dan } \\
\text { username tidak } \\
\text { diisi atau } \\
\text { kosong } \\
\text { kemudian klik } \\
\text { tombol Login }\end{array}$ & $\begin{array}{l}\text { Username: } \\
\text { (kosong) } \\
\text { Password: } \\
\text { admin }\end{array}$ & $\begin{array}{l}\text { Sistem akan } \\
\text { menolak dan } \\
\text { menampilkan pesan } \\
\text { "Username belum } \\
\text { diisi" }\end{array}$ & $\begin{array}{l}\text { Sesuai } \\
\text { harapan }\end{array}$ & sukses \\
\hline 4 & $\begin{array}{l}\text { Mengetikkan } \\
\text { Username } \\
\text { dan/atau } \\
\text { password tidak } \\
\text { sesuai, } \\
\text { kemudian klik }\end{array}$ & $\begin{array}{l}\text { Username: } \\
\text { adm } \\
\text { Password: } \\
\text { adm123 }\end{array}$ & $\begin{array}{l}\text { Sistem akan } \\
\text { menolak dan } \\
\text { menampilkan pesan }\end{array}$ & $\begin{array}{l}\text { Sesuai } \\
\text { harapan }\end{array}$ & sukses \\
\hline
\end{tabular}




\begin{tabular}{|c|c|c|c|c|c|}
\hline \multirow{3}{*}{5} & tombol Login & & $\begin{array}{l}\text { anda masukan } \\
\text { salah" }\end{array}$ & & \\
\hline & $\begin{array}{l}\text { Mengetikkan } \\
\text { Username dan } \\
\text { password }\end{array}$ & $\begin{array}{l}\text { Username: } \\
\text { admin }\end{array}$ & $\begin{array}{l}\text { Sistem menerima } \\
\text { akses login dan } \\
\text { kemudian }\end{array}$ & $\begin{array}{l}\text { Sesuai } \\
\text { harapan }\end{array}$ & sukses \\
\hline & $\begin{array}{l}\text { (diisi), } \\
\text { kemudian klik } \\
\text { tombol Login }\end{array}$ & $\begin{array}{l}\text { Password: } \\
\text { admin }\end{array}$ & $\begin{array}{l}\text { menampilkan } \\
\text { halaman utama } \\
\text { Admin }\end{array}$ & & \\
\hline
\end{tabular}

b. Pengujian form login Anggota

Tabel 2. Hasil pengujian black box testing login anggota

\begin{tabular}{|c|c|c|c|c|c|}
\hline No. & $\begin{array}{c}\text { Skenario } \\
\text { Pengujian }\end{array}$ & Test Case & $\begin{array}{l}\text { Hasil yang } \\
\text { Diharapkan }\end{array}$ & $\begin{array}{c}\text { Hasil } \\
\text { Pengujian }\end{array}$ & Kesimpulan \\
\hline 1 & $\begin{array}{l}\text { Email dan } \\
\text { Password tidak } \\
\text { diisi kemudian } \\
\text { klik tombol } \\
\text { Login }\end{array}$ & $\begin{array}{l}\begin{array}{l}\text { Email: } \\
\text { (kosong) }\end{array} \\
\text { Password: } \\
\text { (kosong) }\end{array}$ & $\begin{array}{l}\text { Sistem akan menolak } \\
\text { dan menampilkan } \\
\text { pesan } \\
\text { "Harap isi Email dan } \\
\text { password" }\end{array}$ & $\begin{array}{l}\text { Sesuai } \\
\text { harapan }\end{array}$ & sukses \\
\hline 2 & $\begin{array}{l}\text { Mengetikkan } \\
\text { Email, dan } \\
\text { password tidak } \\
\text { diisi atau kosong } \\
\text { kemudian klik } \\
\text { tombol Login }\end{array}$ & $\begin{array}{l}\text { Email: } \\
\text { anggota1@gmail.com } \\
\text { Password: } \\
\text { (kosong) }\end{array}$ & $\begin{array}{l}\text { Sistem akan menolak } \\
\text { dan menampilkan } \\
\text { pesan } \\
\text { "Password belum } \\
\text { diisi" }\end{array}$ & $\begin{array}{l}\text { Sesuai } \\
\text { harapan }\end{array}$ & sukses \\
\hline 3 & $\begin{array}{l}\text { Mengetikkan } \\
\text { Password, dan } \\
\text { Email tidak diisi } \\
\text { atau kosong } \\
\text { kemudian klik } \\
\text { tombol Login }\end{array}$ & $\begin{array}{l}\begin{array}{l}\text { Email: } \\
\text { (kosong) }\end{array} \\
\text { Password: } \\
12345\end{array}$ & $\begin{array}{l}\text { Sistem akan menolak } \\
\text { dan menampilkan } \\
\text { pesan } \\
\text { "Email belum diisi" }\end{array}$ & $\begin{array}{l}\text { Sesuai } \\
\text { harapan }\end{array}$ & sukses \\
\hline 4 & $\begin{array}{l}\text { Mengetikkan } \\
\text { Email dan/atau } \\
\text { password tidak } \\
\text { sesuai, kemudian } \\
\text { klik tombol } \\
\text { Login }\end{array}$ & $\begin{array}{l}\text { Username: } \\
\text { a123@gmail.com } \\
\text { Password: } \\
\text { xyz }\end{array}$ & $\begin{array}{l}\text { Sistem akan menolak } \\
\text { dan menampilkan } \\
\text { pesan } \\
\text { "Email atau } \\
\text { Password yang anda } \\
\text { masukan salah" }\end{array}$ & $\begin{array}{l}\text { Sesuai } \\
\text { harapan }\end{array}$ & sukses \\
\hline 5 & $\begin{array}{l}\text { Mengetikkan } \\
\text { Email dan } \\
\text { password (diisi), } \\
\text { kemudian klik } \\
\text { tombol Login }\end{array}$ & $\begin{array}{l}\text { Username: } \\
\text { admin } \\
\text { Password: } \\
\text { Admin }\end{array}$ & $\begin{array}{l}\text { Sistem menerima } \\
\text { akses login dan } \\
\text { kemudian } \\
\text { menampilkan } \\
\text { halaman utama } \\
\text { Anggota }\end{array}$ & $\begin{array}{l}\text { Sesuai } \\
\text { harapan }\end{array}$ & sukses \\
\hline
\end{tabular}

c. Pengujian form pendaftaran online

Tabel 3. Hasil pengujian black box testing pendaftaran anggota online

\begin{tabular}{llllll}
\hline No. & \multicolumn{1}{c}{$\begin{array}{c}\text { Skenario } \\
\text { Pengujian }\end{array}$} & Test Case & \multicolumn{1}{c}{$\begin{array}{c}\text { Hasil yang } \\
\text { Diharapkan }\end{array}$} & $\begin{array}{c}\text { Hasil } \\
\text { Pengujian }\end{array}$ & Kesimpulan \\
\hline 1 & Nama Lengkap, & Mengklik & Sistem akan & Sesuai & sukses \\
& Nama Panggilan, & Daftar tanpa & menolak dan & harapan & \\
Tempat dan & mengisi data & menampilkan & & \\
& Tanggal Lahir, & atau hanya & pesan & & \\
& Usia, Alamat, & sebagian data & & & \\
& Provinsi, & diisi & "Semua data & & \\
Kota/Kab., & & harus diisi" & & \\
& Kecamatan, & & & &
\end{tabular}




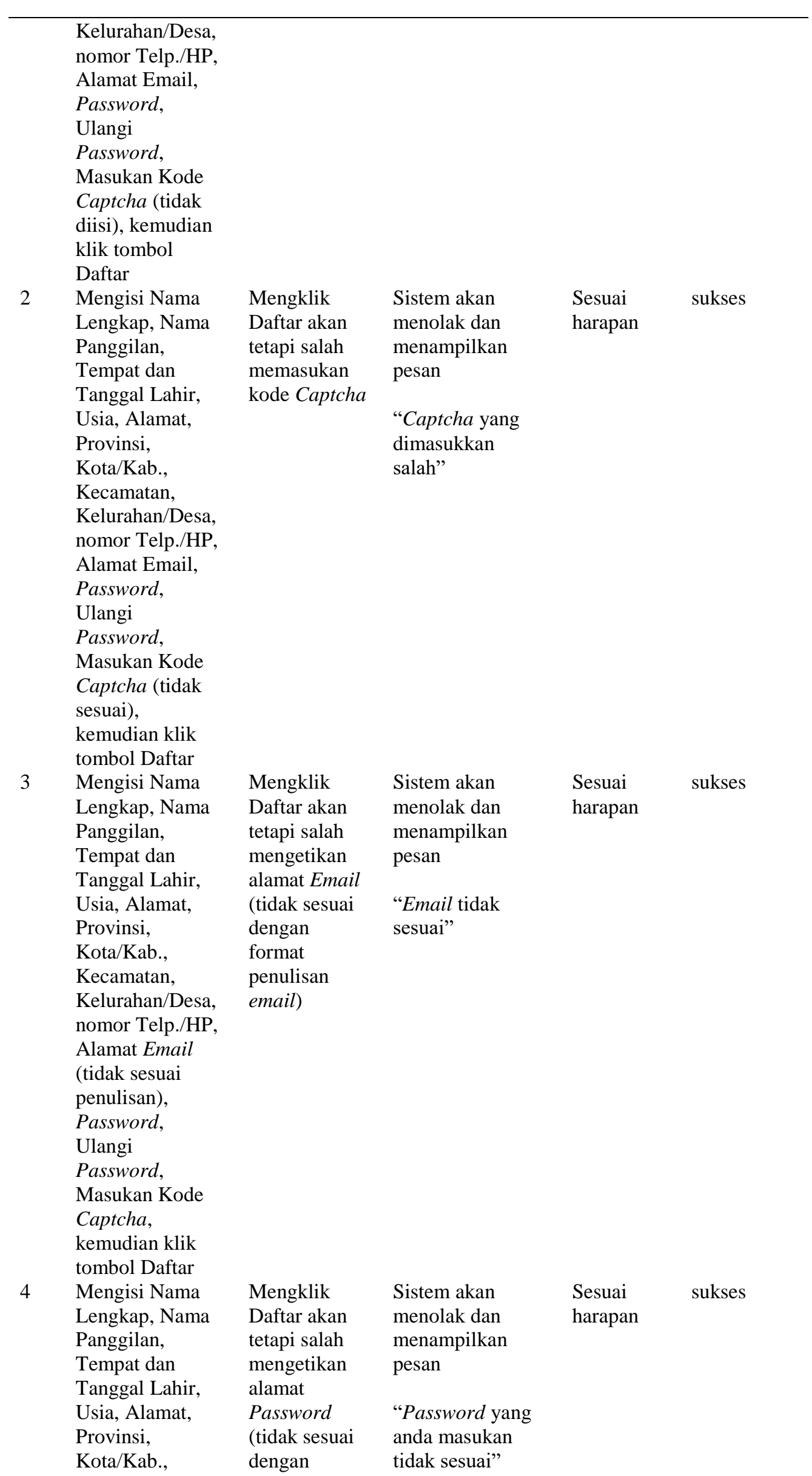




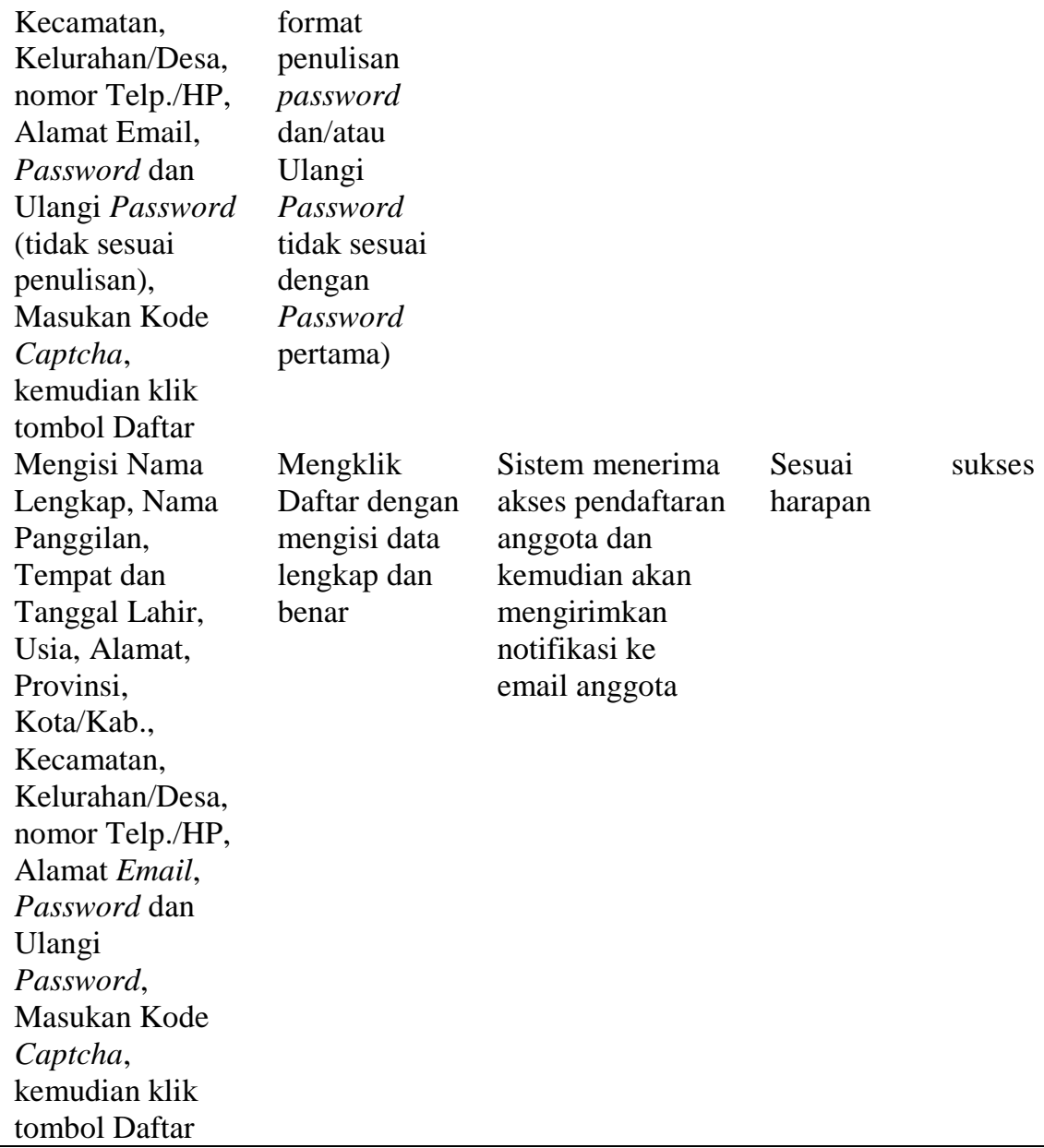

Kecamatan, format

Kelurahan/Desa, penulisan

nomor Telp./HP, password

Alamat Email, dan/atau

Password dan Ulangi

Ulangi Password Password

(tidak sesuai tidak sesuai

penulisan), dengan

Masukan Kode Password

Captcha, pertama)

kemudian klik

tombol Daftar

Lengkap, Nama

Panggilan,

Tempat dan

Tanggal Lahir,

Usia, Alamat,

Provinsi,

Kota/Kab.,

Kecamatan,

Kelurahan/Desa,

nomor Telp./HP,

Alamat Email,

Password dan

Ulangi

Password,

Masukan Kode

Captcha,

kemudian klik

tombol Daftar

5 Mengisi Nama

d. Pengujian form Input konsultasi

Tabel 4. Hasil pengujian black box testing input konsultasi

\begin{tabular}{|c|c|c|c|c|c|}
\hline No. & $\begin{array}{c}\text { Skenario } \\
\text { Pengujian }\end{array}$ & Test Case & $\begin{array}{c}\text { Hasil yang } \\
\text { Diharapkan } \\
\end{array}$ & $\begin{array}{c}\text { Hasil } \\
\text { Pengujian }\end{array}$ & Kesimpulan \\
\hline 1 & $\begin{array}{l}\text { Judul dan Isi } \\
\text { Konsultasi serta } \\
\text { kode Captcha } \\
\text { tidak diisi } \\
\text { kemudian klik } \\
\text { tombol Kirim }\end{array}$ & $\begin{array}{l}\text { Mengklik Kirim } \\
\text { tanpa mengisi data } \\
\text { atau hanya sebagian } \\
\text { data diisi }\end{array}$ & $\begin{array}{l}\text { Sistem akan menolak } \\
\text { dan menampilkan } \\
\text { pesan } \\
\text { "Semua data harus } \\
\text { diisi" }\end{array}$ & $\begin{array}{l}\text { Sesuai } \\
\text { harapan }\end{array}$ & sukses \\
\hline 2 & $\begin{array}{l}\text { Mengisi Judul } \\
\text { dan Isi } \\
\text { Konsultasi serta } \\
\text { kode Captcha } \\
\text { (tidak sesuai) } \\
\text { kemudian klik } \\
\text { tombol Kirim }\end{array}$ & $\begin{array}{l}\text { Mengklik Daftar } \\
\text { akan tetapi salah } \\
\text { memasukan kode } \\
\text { Captcha }\end{array}$ & $\begin{array}{l}\text { Sistem akan menolak } \\
\text { dan menampilkan } \\
\text { pesan } \\
\text { "Captcha yang } \\
\text { dimasukkan salah" }\end{array}$ & $\begin{array}{l}\text { Sesuai } \\
\text { harapan }\end{array}$ & sukses \\
\hline 3 & $\begin{array}{l}\text { Mengisi Judul } \\
\text { dan Isi } \\
\text { Konsultasi serta } \\
\text { kode Captcha, } \\
\text { kemudian klik } \\
\text { tombol Kirim }\end{array}$ & $\begin{array}{l}\text { Mengklik Kirim } \\
\text { dengan mengisi data } \\
\text { lengkap dan benar }\end{array}$ & $\begin{array}{l}\text { Sistem menerima akses } \\
\text { input konsultasi dan } \\
\text { kemudian akan } \\
\text { mengirimkan notifikasi } \\
\text { ke email anggota }\end{array}$ & $\begin{array}{l}\text { Sesuai } \\
\text { harapan }\end{array}$ & sukses \\
\hline
\end{tabular}




\subsubsection{Pengujian T Test}

Untuk mengukur efektivitas pengaruh Aplikasi sistem konsultasi kesehatan berbasis web terhadap keinginan utk meningkatkan ketrampilan hidup sehat, sampel diambil 25 orang untuk menguji aplikasi sistem Konsultasi kesehatan berbasis web. Dengan taraf signifikansi $\alpha=0.05$. Apakah terdapat pengaruh Aplikasi sistem konsultasi kesehatan berbasis web terhadap keinginan untuk meningkatkan ketrampilan hidup sehat.

a. Analisa Hipotesis

$\mathrm{Ho}=\mu 1-\mu 2=0$

$\mathrm{H} 1=\mu 1-\mu 2 \neq 0$

b. Uji statistik $t_{\text {hit }}(\mathrm{n}<30), \alpha=0.05$

Wilayah kritik $t_{h i t}<\mathrm{t} \alpha ;(\mathrm{n}-1)$ atau $t_{h i t}>\mathrm{t} \alpha ;(\mathrm{n}-1)$

c. Perhitungan

$$
\begin{aligned}
& t=\frac{\bar{D}}{S D / \sqrt{n}} \\
& t=\text { nilai hitung } \\
& \bar{D}=\text { Rata- rata sampel } \\
& \mathrm{SD}=\text { Standar Deviasi } \\
& \mathrm{n}=\text { jumlah sampel } \\
& \bar{D}=\frac{184}{25}=7.4 \quad=\frac{1}{24}(556) \\
& \text { Variansi }\left(\mathrm{S}^{2}\right)=\frac{1}{n-1} \sum_{i=n}^{n}((\mathrm{xj}-\mathrm{xi})-\bar{D})^{2} \\
& \quad \begin{array}{l}
\mathrm{S}=\sqrt{23.17} \quad=23.17 \\
=4.81 \quad
\end{array} \\
& \mathrm{t}=\frac{\overline{\mathrm{D}}}{\mathrm{SD} / \sqrt{\mathrm{n}}} \\
& =\frac{7.4}{\frac{4.81}{\sqrt{25}}} \\
& =3.08
\end{aligned}
$$

Karena $\mathrm{t}_{\text {hitung }}=3.08>\mathrm{t} 0,05 ; 25=2,060$. $\mathrm{t}$ hitung memiliki nilai lebih besar maka aplikasi konsultasi kesehatan berbasih web memberikan pengaruh peningkatan cara hidup sehat

\section{SIMPULAN DAN SARAN}

Berdasarkan hasil dari penelitian maka dapat disimpulkan

a. Web ini menyediakan informasi tentang puskesmas Karang satria Tambun Utara

b. Web ini menyediakan fitur konsultasi secara online yang dapat dimanfaatkan oleh Anggota

c. Database konsultasi online dapat dijadikan sebagai catatan history file bagi Anggota.

d. Hasil dari penelitian ini dapat memberikan masukan dan manfaat, khususnya pada

e. kegiatan pelayanan kesehatan dan penyuluhan remaja (PKPR) di puskesmas wilayah Bekasi dan sekitarnya.

Berikut saran-saran yang dapat penulis sampaikan berkaitan dengan rancangan sistem informasi PKPR berbasis web:

a. Untuk pengembangan selanjutnya diharapkan dapat memberikan informasi atau laporan datadata yang lebih meluas dalam cakupan Pelayanan Kesehatan Peduli Remaja di Puskesmas Bekasi.

b. Sistem Informasi PKPRberbasis web ini akan lebih lengkap jika dikembangkan menggunakan sms gateway dan balasan melalui e-mail sehingga selain mendapatkan informasi melalui web, Anggota juga dapat memperoleh informasi dengan layanan sms gateway dan e-mail, serta pelayanan terhadap Anggota dan Petugas menjadi lebih maksimal. 


\section{UCAPAN TERIMA KASIH}

Ucapan terimakasih kami berikan yang sebanyak-banyaknya kepada seluruh petugas PKPR di Puskesmas Karangsatria, Tambun Utara, Bekasi.

\section{DAFTAR PUSTAKA}

[1] Y. Utama, "SISTEM INFORMASI BERBASIS WEB JURUSAN SISTEM INFORMASI," Jurnal Sistem Informasi (JSI), vol. 3, no. No. 2, Oktober, pp. 359-370, 2011.

[2] V. Rivai and A. Permata, Credit Management Handbook, Bekasi: Raja Grafindo Persada, 2006.

[3] J. Simarmata, Rekayasa Perangkat Lunak, Yogyakarta: Andi Offset, 2010.

[4] G. S., "Relationship Marketing Dan Pemanfaatan Teknologi Informasi Dalam Customer Relationship Management Untuk Memenangkan Persaingan Bisnis," in Seminar Nasional Aplikasi Teknologi Informasi 2005 (SNATI 2005), Yogyakarta, 2005.

[5] J. Dyche, The CRM Handbook, USA: Addison-Wesley, 2002.

[6] R. Kalakota and M. Robinson, E-Business 2.0 - Roadmap For Success, USA: Addison-Wesley Longman Inc., 2001.

[7] W. A. Tunggal, Konsep Dasar Customer Relationship Managemen, Jakarta: Harvarindo, 2000.

[8] R. A. Sukamto and . M. Shalahuddin, Rekayasa Perangkat Lunak, Bandung: Informatika, 2013.

[9] S. Bahri and S. Dalis, "Rancang Bangun E-Enrollment Berbasis Web Menggunakan Customer Relationship Management (CRM) Pada Sekolah Dasar Islam Terpadu," Jurnal Teknik Komputer, vol. 4, no. No. 1, Februari, pp. 205-211, 2018.

[10] E. Winarko, Perancangan Database dengan Power Designer, Jakarta: Prestasi Pustaka, 2006. 